\title{
A Semi-Continuous Analyzer for the Fluorimetric Determination of Atmospheric Formaldehyde
}

\author{
Eliane Teixeira Sousa, ${ }^{a}$ Fabio Santos de Oliveira, ${ }^{a, b}$ Arnaldo Cardoso Alves ${ }^{c}$ and Jailson B. de Andrade ${ }^{*, a, d}$ \\ ${ }^{a}$ Instituto de Química and ${ }^{d}$ Centro Interdisciplinar de Energia e Ambiente, Universidade Federal da Bahia, \\ Campus Universitário de Ondina, 40170-115 Salvador-BA, Brazil
}

${ }^{b}$ Centro de Ciências da Saúde, Universidade Federal do Recôncavo da Bahia, Cajueiro, 44570-000 Santo Antonio de Jesus-BA, Brazil

'Instituto de Química, Universidade Estadual Paulista, CP 355, 14801-970 Araraquara-SP, Brazil

Este trabalho descreve o analisador semi-contínuo (FORMAL-FLU) sensível e seletivo para determinação fluorimétrica de formaldeído no ar atmosférico. O método é baseado na reação entre formaldeído e Fluoral-P, produzindo o derivado fluorescente 3,5-diacetil-1,4-diidrolutidina (DDL), que quando excitado em $410 \mathrm{~nm}$, emite fluorescência em $510 \mathrm{~nm}$. O analisador consiste de uma câmara difusora de gases com um tubo de teflon microporoso, com alta permeabilidade, preenchido com solução de Fluoral-P. A amostra de ar é bombeada continuamente ao longo do tubo externo e o formaldeído permeia a membrana do tubo interno, onde reage seletivamente com Fluoral-P para formar o DDL. Os parâmetros analíticos, vazão de amostragem, tempo de amostragem e vazão de Fluoral-P foram otimizados pelo método da superfície de resposta, usando o desenho Box-Behnken. Sob as condições otimizadas, amostras de ar foram bombeadas através do espaço anular da câmara de difusão gasosa que é equipada com um tubo central de teflon microporoso (17 cm comprimento, 1,4 mm d.i., 2,15 mm d.e., $70 \%$ de porosidade e $2 \mu \mathrm{m}$ de diâmetro médio de poro) preenchido com Fluoral-P, à vazão de $2,5 \mathrm{~L} \mathrm{~min}^{-1}$ por 30 min. Após a amostragem, a mistura foi direcionada à vazão de $1,3 \mathrm{~mL} \mathrm{~min}^{-1}$, para a bobina de reação de $2,0 \mathrm{~m}$, imersa em um banho termostático a $80^{\circ} \mathrm{C}$, para melhorar a mistura amostra/reagente e a velocidade de reação, chegando então ao detector fluorimétrico $\left(\lambda_{\mathrm{ex}}=410 \mathrm{~nm} \lambda_{\mathrm{em}}=510 \mathrm{~nm}\right)$, onde o sinal foi adquirido, e registrado por um integrador. As alturas de pico foram medidas e esses valores foram usados na calibração e determinação. Sob estas condições, o limite de detecção foi $0,55 \mathrm{ng} \mathrm{mL}^{-1}$ e o coeficiente de variação foi 8,6\%. A maior vantagem do FORMAL-FLU é sua seletividade para formaldeído, sem interferência significativa de bissulfito e de outros aldeídos, especialmente acetaldeído, e baixo nível de branco, resultando em baixo limite de detecção. FORMAL-FLU acopla a amostragem e a análise em um único equipamento, permitindo assim medidas in situ.

This paper describes a sensitive and selective semi-continuous analyzer (FORMAL-FLU) for the fluorimetric determination of atmospheric formaldehyde. The method is based on the reaction between formaldehyde and Fluoral-P, producing the fluorescent derivative 3,5-diacetyl-1,4-dihydrolutidine (DDL) which, when excited at $410 \mathrm{~nm}$, fluoresces at $510 \mathrm{~nm}$. This analyzer consists of a gas diffusion chamber with a central microporous Teflon tube, with high gas permeability, filled with Fluoral-P solution. The air sample is pumped continually along the external tube and formaldehyde permeates the internal tube membrane, where it reacts selectively with Fluoral-P to form DDL. The analytical parameters of air sampling flow rate, sampling time interval and Fluoral-P reagent flow rate were optimized by the response surface method, using the Box-Behnken design. Under optimal conditions, air samples were pumped through the annular space of a gas diffusion chamber equipped with a central tube of microporous Teflon (17 cm long, $1.4 \mathrm{~mm}$ i.d., $2.15 \mathrm{~mm}$ e.d., $70 \%$ of porosity and $2 \mu \mathrm{m}$ average pore diameter) filled with Fluoral-P at $2.5 \mathrm{~mL} \mathrm{~min}^{-1}$ for $30 \mathrm{~min}$. After sampling, the mixture was directed at $1.3 \mathrm{~mL} \mathrm{~min}^{-1}$ to a $2.0 \mathrm{~m}$ long reaction coil immerged in a thermostatic bath at $80^{\circ} \mathrm{C}$ to improve the sample/reagent mixture and reaction rate, then to the fluorimetric detector $\left(\lambda_{\mathrm{ex}}=410 \mathrm{~nm} \lambda_{\mathrm{em}}=510 \mathrm{~nm}\right)$, where the signal was acquired and recorded by an integrator. Peak heights were measured and these values were used in the calibration and determination steps. Under these conditions, the limit of detection was $0.55 \mathrm{ng} \mathrm{mL}^{-1}$ and the coefficient of variation was $8.6 \%$. The main advantage of the FORMAL-FLU system is its selectivity for formaldehyde, without significant interference from bisulfite and other aldehydes, especially acetaldehyde, low blank level, resulting in low detection limits and, above all, using a single sampling and measuring device equipment which allows for in situ measurements.

Keywords: semi-continuous analyzer, formaldehyde, fluoral-P

*e-mail: jailsong@ufba.br 


\section{Introduction}

Formaldehyde (HCHO) is the most abundant aldehyde in ambient air and is ubiquitous in urban atmospheres, where it is introduced through a variety of emission pathways. This aldehyde is of great significance in atmospheric chemistry due to its strong influence on atmospheric photochemical reactions that lead to the formation of important smog components. ${ }^{1-3}$

Formaldehyde, which is present in ambient air at high concentrations, undergoes chemical reactions and physical transformations during its trajectory through the atmosphere. ${ }^{2-5}$ Atmospheric formaldehyde levels may reach concentrations ranges of $0.1-1.8 \mathrm{ppbV}$ in remote areas, $1.2-113 \mathrm{ppbV}$ in urban areas and 2.3-188 ppbV in indoor environments. The higher concentrations indoors and in urban areas are due to the numerous sources of direct emission of this compound. ${ }^{1-3,5-17}$

Formaldehyde emissions have received a great deal of attention due to their known mutagenic and carcinogenic nature and their toxicity, which is manifested by irritation of the eyes and respiratory tract, nausea, headache, tiredness and thirst. ${ }^{1,6}$ Although there is no evidence of the carcinogenicity of formaldehyde in humans, the specific effects of continuous exposure on infants, young children and pregnant women have yet to be determined. ${ }^{1}$

A large amount of information on atmospheric levels of formaldehyde has been generated, most of it based on measurements of the gas phase. The sampling systems most commonly used for collecting atmospheric formaldehyde are impingers containing acidic solutions of 2,4-dinitrophenylhydrazine (2,4-DNPH), bisulfite-coated cellulose filters or denuders and cartridges (Florisil, silica or C18) coated with 2,4-DNPH, followed by quantification by gas chromatography/FID or liquid chromatography/ UV-Vis. ${ }^{2,3,5-17}$ However, chromatographic methods are slow, laborious and not specific for formaldehyde.

Colorimetric methods involving the pararosanilinebased Schiff reaction has been widely used to determine formaldehyde, ${ }^{18-21}$ but the color development is relatively slow and sensitivity is limited. ${ }^{22}$ Among the spectrometric methods, the reaction with 2,4-pentanedienone (Figure 1) and fluorimetric detection is the most sensitive and specific method, ${ }^{19,23-27}$ since acetaldehyde does not interfere even when it is present in concentrations 1000-fold higher than formaldehyde. ${ }^{8,28,29}$

This paper describes a sensitive and selective semicontinuous analyzer (FORMAL-FLU) for the fluorimetric determination of formaldehyde in air. The method is based on the reaction between formaldehyde and Fluoral-P, producing the fluorescent derivative 3,5-diacetyl-1,4dihydrolutidine (DDL) which emits fluorescence at $510 \mathrm{~nm}$ when excited at $410 \mathrm{~nm}$.

The analytical parameters air sampling flow rate, sampling time interval and Fluoral-P reagent flow rate were optimized by the response surface method, using the Box-Behnken design. ${ }^{29}$ The FORMAL-FLU analyzer has been used for the determination of gas phase formaldehyde in both indoor and outdoor sites.

\section{Experimental}

\section{Reagents}

All the reagents used in this study were of analytical grade. Water was distilled and deionized in an E-pure system (Barnstead). Fluoral-P was prepared by reaction of acetic acid glacial $100 \%$ Merck $(0.3 \mathrm{~mL})$, acetylacetone para sintese Merck $(0.2 \mathrm{~mL})$ and ammonium acetate J. T. Baker $97.3 \%$ (15.4 g). The volume was then topped up to $100 \mathrm{~mL}$ with deionized water. The reaction with 2,4-pentanedione and ammonia to procedure Fluoral-P is shown in Figure 2.

To improve the blank levels, acetylacetone should be purified by distillation in the presence of potassium permanganate before it is used. The highest fluorescence values were obtained when the Fluoral-P was buffered at $\mathrm{pH}$ 6. This reagent, if stored under refrigeration $\left(4^{\circ} \mathrm{C}\right)$ and in the dark, can be used safely for 60 days. ${ }^{8,28,29}$<smiles>CC(=O)c1c(C)[nH+]c(C)c(C(C)=O)c1C(C)=O</smiles>

Figure 1. Reaction between formaldehyde and Fluoral-P producing 3,5-diacetyl-dihydrolutidine (DDL).

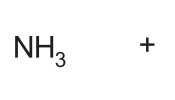<smiles>CC(=O)CC(C)=O</smiles>

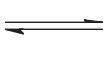<smiles>CC(=O)C=C(C)N</smiles>

Figure 2. Reaction between ammonia and 2,4-pentanedione, producing Fluoral-P. 
The 2,4-DNPHi solution was prepared by dissolution of $0.05 \mathrm{~g}$ of 2,4-DNPHi in $60 \mathrm{~mL}$ of acetonitrile, $39 \mathrm{~mL}$ of water and $1.0 \mathrm{~mL}$ of $\mathrm{H}_{3} \mathrm{PO}_{4}$. The solution was then purified by three successive extractions with $\mathrm{CCl}_{4}$. Details of the 2,4-DNPHi preparation and purification procedures have been described previously. ${ }^{30,31}$ This solution was used to coat SEP PAK C18 cartridges for HPLC analysis. Details of the cartridge preparation are also previously reported elsewhere. . $^{3,8,15,32}$

A formaldehyde stock solution (1 L, $1000 \mathrm{ppm}$ ) was prepared by diluting $37 \%(\mathrm{~m} / \mathrm{v})$ of formaldehyde in water. This solution was stored at $4{ }^{\circ} \mathrm{C}$ and its concentration was checked by HPLC before use.

\section{Gaseous formaldehyde standard}

To validate the method, gaseous formaldehyde standards were prepared in a $250 \mathrm{~L}$ Teflon (PTFE) film chamber, transparent to the solar radiation ${ }^{8,32,33}$ by the injection of varied known volumes of an aqueous standard formaldehyde solution into the Teflon chamber, using purified air to carry out the $\mathrm{HCHO}$. The final concentrations obtained were in the range of $\left(0.87 \mu \mathrm{g} \mathrm{L}^{-1}\right.$ to $\left.9.84 \mu \mathrm{g} \mathrm{L}^{-1}\right)$. After each use, the chamber was cleaned by flushing it three times with purified air and evacuating it with a vacuum pump. The chamber was cleaned further by adding ozone and letting it react with any impurities overnight.

\section{Apparatus}

An HPLC fluorescence detector (Spectra-Physics FS-970-DA1), set at $\lambda_{\text {ex }}=410 \mathrm{~nm} \lambda_{\text {em }}=510 \mathrm{~nm}$, was used to measure the DDL fluorescent emission. A Miniplus 3 (Gilson, France) peristaltic pump was utilized for fluid propulsion. The flow system was equipped with polyethylene and PTFE tubes $(0.8 \mathrm{~mm}$ i.d.) used, respectively, as peristaltic and connection tubes.

The HPLC pump (Varian, model 2510, CA) was equipped with a Rheodyne injector and a variable UV-Vis detector (Varian model 2550). To reach the lowest formaldehyde detection limit, the wavelength and sensitivity detector were set at $365 \mathrm{~nm}$ and 0.04 AUFS, respectively. The analytical column was an Econosphere C18 (5 $\mu \mathrm{m}$, $250 \mathrm{~mm} \times 4.6 \mathrm{~mm}$ i.d. Alltech). The mobile phase was methanol:acetonitrile:water $(74.5 / 0.5 / 25 \%, \mathrm{v} / \mathrm{v} / \mathrm{v})$ at $1.0 \mathrm{~mL} \mathrm{~min}$. . Details of the analytical procedure can be found elsewhere. ${ }^{3,8,15,32} \mathrm{~A}$ zero air supplier (model 111, Thermo Environmental Inc.) was used in the preparation of the gaseous formaldehyde standards. Statistica 6.0 (Statsoft, USA) was used for the calculations involved in the multivariate response surface optimization.

\section{Formaldehyde analyzer}

The formaldehyde collector is shown schematically in Figure 3. This collector consisted of a microporous PTFE membrane tube (17 cm long, $1.4 \mathrm{~mm}$ i.d., $2.15 \mathrm{~mm}$ e.d., $70 \%$ of porosity and $2 \mu \mathrm{m}$ average pore diameter) connected to two plastic tees and arranged inside a Teflon jacket tube ( $8.0 \mathrm{~mm}$ i.d., and $19 \mathrm{~cm}$ in length). The microporous tube was filled with the Fluoral-P reagent solution buffered at $\mathrm{pH} 6$. A scheme of proposed analyzer is depicted at Figure 4.

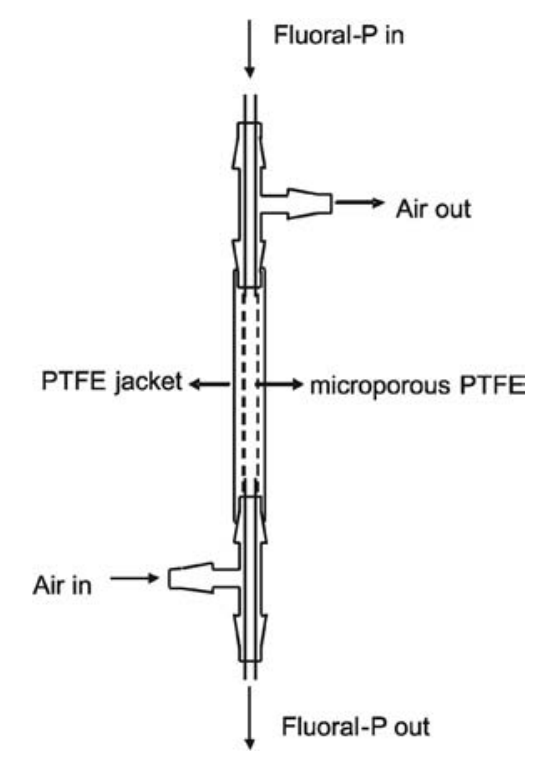

Figure 3. Reaction chamber made of a $17 \mathrm{~cm}$ long microporous Teflon tube, with $1.4 \mathrm{~mm}$ i.d. and $2.15 \mathrm{~mm}$ e.d., connected to two plastic tees and arranged inside a Teflon jacket tube with $8.0 \mathrm{~mm}$ i.d., and $19 \mathrm{~cm}$ in length.

The air sampling stage (Figure 4A) was performed by aspiration of atmosferic air with flow direction parallel to the axis of the microporous tube, and the formaldehyde permeated thorough the microporous tube walls, reacting with the Fluoral-P to form the fluorescent compound (Figure 1). Once peristaltic pump was turned off during air sampling step, Fluoral-P channel was at stopped flow mode.

A further determination stage (Figure 4B) was carried out by interruption of air flow and activation of peristaltic pump, then the Fluoral-P carrier solution propelled the formaldehyde/ Fluoral-P mixture zone to a reaction coil immerged in a thermostatic bath and to the fluorimetric flow cell. After the record of the transient analytical signal, the formaldehyde collector device was ready to a new sampling stage.

\section{Results and Discussion}

It was observed that the efficiency of the derivatization reaction decreased as the concentration of ammonium diminished. ${ }^{34}$ To ensure a high analytical signal and reduce 

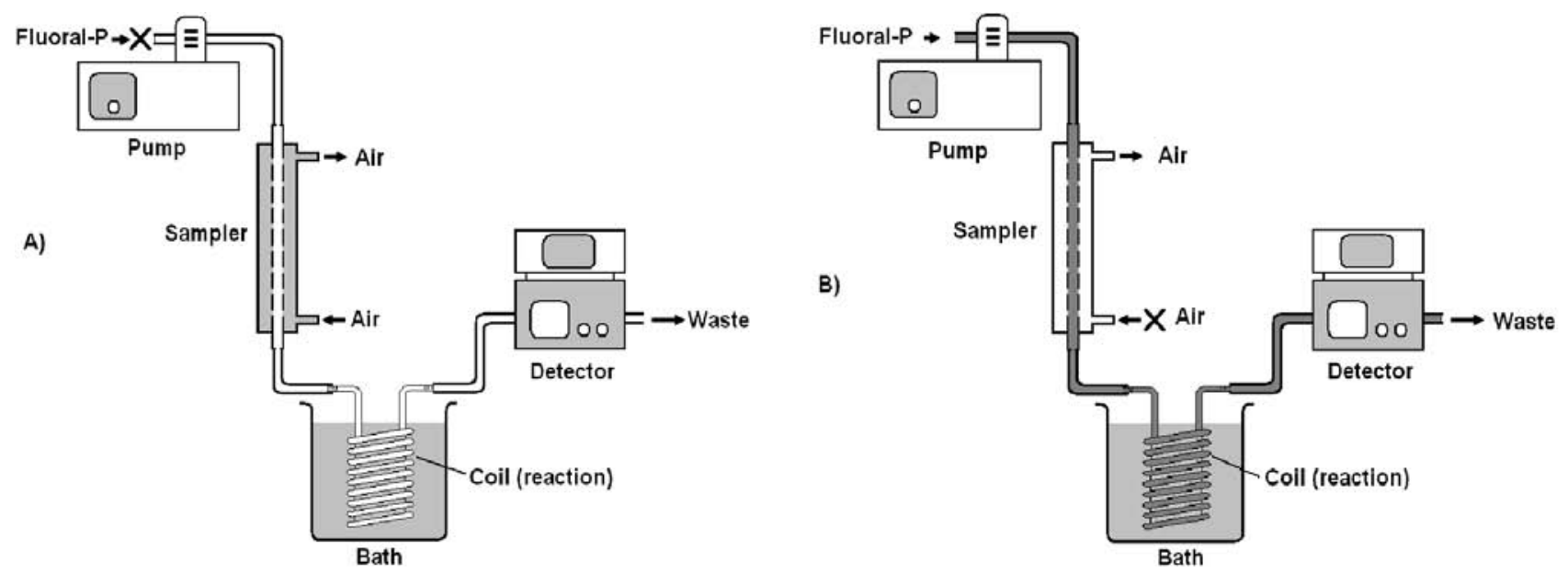

Figure 4. FORMAL-FLU a system like flow analysis: (A) sampling mode; (B) analysis mode.

the consumption of reagent, concentrations of ammonium acetate in the range of $1.0 \mathrm{~mol} \mathrm{~L}^{-1}$ to $4.0 \mathrm{~mol} \mathrm{~L}^{-1}$ were studied. As can be seen in Figure 5, the increasing of ammonium acetate concentration resulted in higher analytical signal. A concentration of $2.0 \mathrm{~mol} \mathrm{~L}^{-1}$ was therefore chosen, since the analytical signal at this concentration increases less sharply but is still satisfactory and less reagent is consumed.

In the optimization of the formaldehyde collector, various parameters such as temperature and coil length were tested in order to identify the best analytical signal.

\section{Effect of reaction coil temperature}

To reduce the reaction time required to attain the maximum formation of the fluorescent product, a reaction coil was placed in a thermostatic water bath to heat the Fluoral-P sample segment and thus accelerate the formation of DDL. The temperatures studied here ranged from $40^{\circ} \mathrm{C}$ to $90^{\circ} \mathrm{C}$. A heating temperature of $80^{\circ} \mathrm{C}$ was adopted, since higher temperatures did not significantly increase the analytical signals and led to the formation of air bubbles (Figure 6).

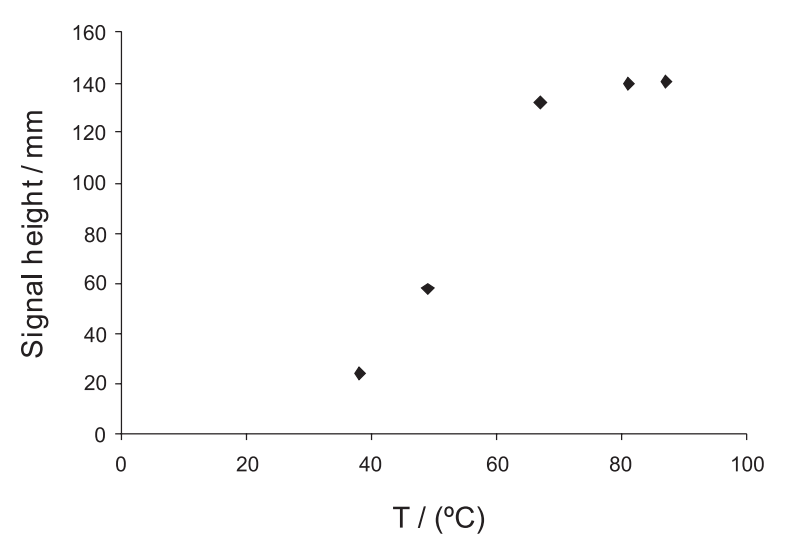

Figure 5. Effect of heating time on fluorescent emission.

\section{Effect of reaction coil length}

Extending the coil length from $0.5 \mathrm{~m}$ to $2.0 \mathrm{~m}$ enhances the analytical signal (Figure 7). This effect can be related to the increase in the residence time of the reactive mixture in the heated system, which favors the reaction. However, it is known that extending the length of the reaction coil increases the dispersion of the sample in the carrier fluid, and that the aforementioned effect can overlap, causing a drop in the analytical signal. The best results were obtained with a reaction coil length of $2.0 \mathrm{~m}$.

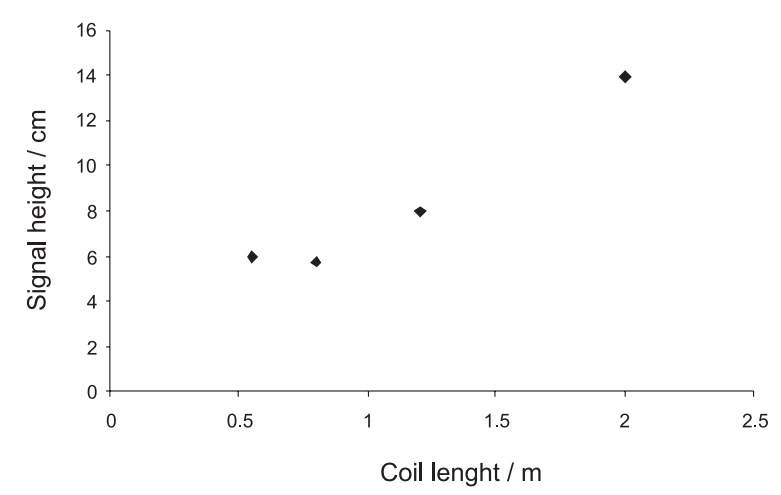

Figure 6. Effect of reaction coil length on the analytical signal.

Optimization by the response surface method

The sensitivity of the proposed flow system was optimized by adopting a multivariate optimization design to evaluate the influence of the Fluoral-P flow rate and air sampling flow rate on the analytical signal. A Box-Behnken design ${ }^{29,35,36}$ was adopted for the multivariate optimization. Table 1 presents the levels of the variables evaluated here, while Figure 8 illustrates the response surface obtained. The equation that described the response surface with 


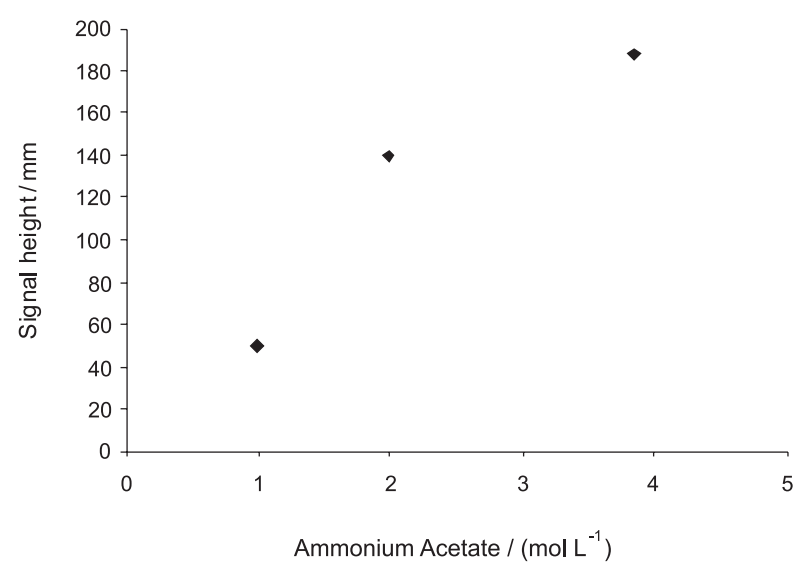

Figure 7. Effect of the concentration of ammonium acetate on the analytical signal.

variable at coded levels was $\mathrm{R}=3.2+0.7 \mathrm{AFR}-0.4 \mathrm{FFR}+$ $0.5 \mathrm{FFR}^{2}+1.6 \mathrm{ST}+0.5 \mathrm{AFR} \mathrm{ST}(\mathrm{R}=$ peak height, $\mathrm{AFR}=$ air flow rate, FFR = Fluoral-P flow rate, $\mathrm{ST}=$ sampling time). The examination of response surface equation shows the absence of quadratic terms for air flow rate and sampling time and positive linear terms for both parameter and consequent absence critical points for these variables, pointing out that increasing air flow rate and sampling time would lead greater sensitivity. On other, considering the quadratic term for Fluoral-P flow rate the optimum value for this variable was found to be $1.3 \mathrm{~mL} \mathrm{~min}^{-1}$.

Table 1. Experimental levels employed for Box-Behnken optimization design

\begin{tabular}{lcc}
\hline Variables & Level (+) & Level (-) \\
\hline Sampling flow rate / $\left(\mathrm{L} \mathrm{min}^{-1}\right)$ & 2.5 & 0.7 \\
Fluoral-P flow rate / $\left(\mathrm{mL} \mathrm{min}^{-1}\right)$ & 1.5 & 0.5 \\
Sampling time / $\min$ & 30 & 10 \\
\hline
\end{tabular}

An increase in the sample's flow rate from $2.5 \mathrm{~L} \mathrm{~min}^{-1}$ to $3.0 \mathrm{~L} \mathrm{~min}^{-1}$ while keeping the other variables unchanged did not significantly increase the analytical signal $(8.57 \%$ increase). Therefore, since a higher flow rate would augment the pressure inside the microporous tube, resulting in leaks and loss of efficiency, this parameter was kept unaltered, i.e. a $2.5 \mathrm{~L} \mathrm{~min}^{-1}$ flow rate.

A comparison of the signal obtained with analytical sampling times of 30 and $37 \mathrm{~min}$ indicated a gain of $31.3 \%$ in the magnitude of the signal, with an experimental error of $7.5 \%$. However, the increase in sampling time impairs the

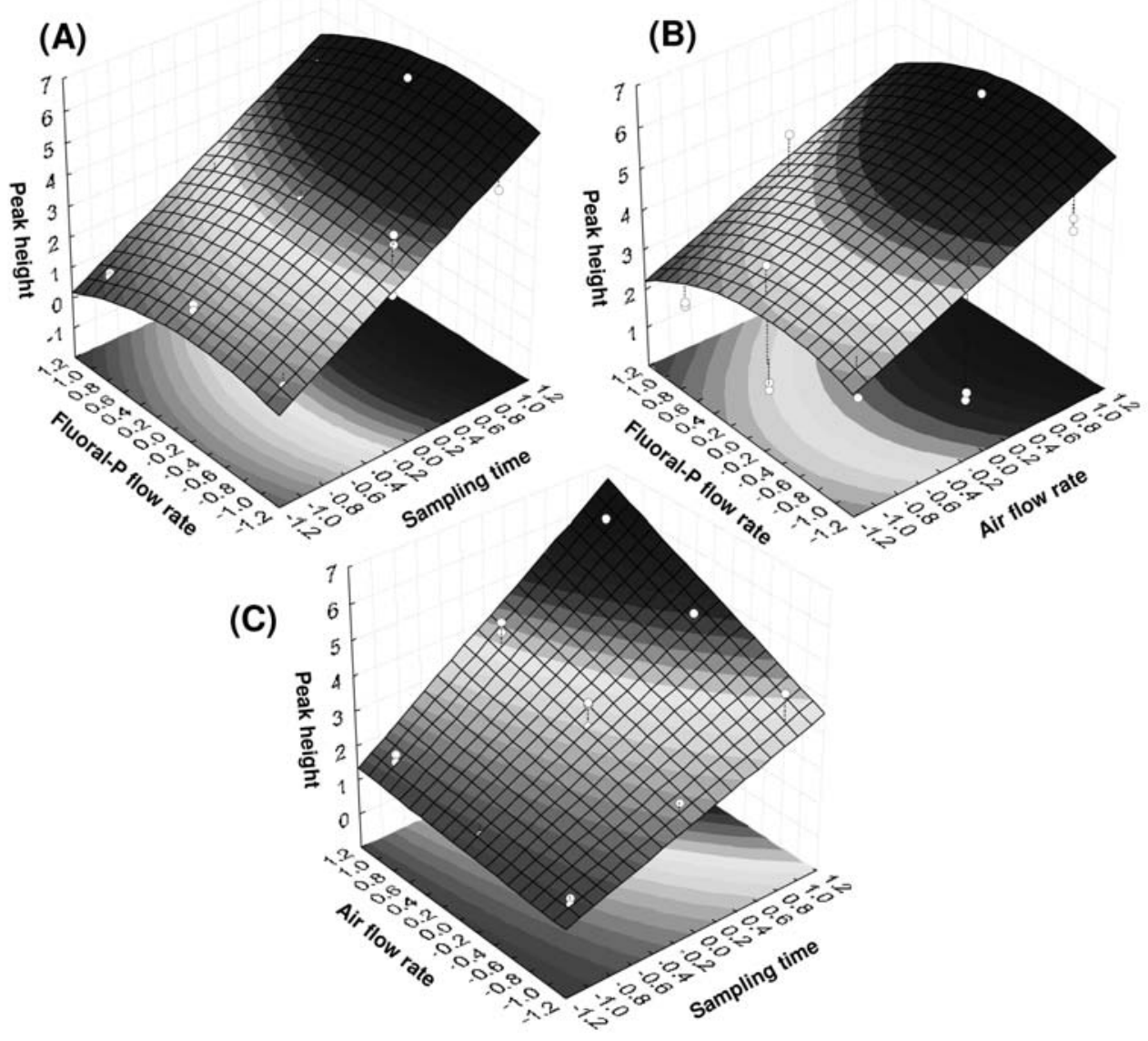

Figure 8. Response surface obtained with the Box-Behnken design. 
speed of the system and, in this case, the increased gain in the signal does not justify the longer analysis time. Since 30 min of sampling time proved sufficient to determine the analyte in unpolluted areas, this sampling time was adopted in our investigations. It should be noted, however, that the time sampling may be considerably shorter in polluted areas. Thus, the optimal conditions for the flow system were attained with a $2.0 \mathrm{~m}$ reaction coil, a temperature of $80{ }^{\circ} \mathrm{C}$, an air flow rate of $2.5 \mathrm{~L} \mathrm{~min}^{-1}$ and a Fluoral-P flow rate of $1.3 \mathrm{~mL} \mathrm{~min}^{-1}$.

\section{Sampling efficiency}

The collection efficiency of the analyzer is calculated according to the type of flow that occurs in the system. The parameter that describes the type of flow is the Reynolds number, ${ }^{37}$ which is calculated as follows:

$\operatorname{Re}=4 \mathrm{~F} / \mathrm{V} \pi\left(\mathrm{d}_{1}+\mathrm{d}_{2}\right)$

where Re is Reynolds number, $\mathrm{F}$ is air flow rate throughout the analyzer $\left(2.5 \mathrm{~L} \mathrm{~min}^{-1}\right), \mathrm{V}$ is air viscosity $\left(1.82 \times 10^{-5} \mathrm{~Pa} \mathrm{~s}\right)$, $\mathrm{d}_{1}$ is inner microporous tube diameter (Teflon) $(2.5 \mathrm{~mm}$ ) and $\mathrm{d}_{2}$ is external tube diameter $(8.0 \mathrm{~mm})$.

Equation (1) yielded a Reynolds number of $\mathrm{Re}=$ $1.67 \times 10^{7}$, indicating that the geometry of the analyzer met the conditions of a turbulent flow, since laminar flow is characterized by $\mathrm{R} \leq 2000$.

The collection efficiency was determined by equation $2 .{ }^{37}$

$\mathrm{C} / \mathrm{C}_{0}=0.82 \mathrm{e}^{-22.53 \Delta}$

where $\Delta=(\pi \mathrm{D} \mathrm{L}) /(4 \mathrm{~F}) \times\left(\mathrm{d}_{1}+\mathrm{d}_{2}\right) /\left(\mathrm{d}_{2}-\mathrm{d}_{1}\right)$, D is formaldehyde diffusion coefficient $\left(0.16 \mathrm{~cm}^{2} \mathrm{~s}^{-1}\right), \mathrm{L}$ is sampling length $(17 \mathrm{~cm}), \mathrm{F}$ is air flow rate through the analyzer $\left(2.5 \mathrm{~L} \mathrm{~min}^{-1}\right), \mathrm{d}_{1}$ is inner diameter of the microporous tube (Teflon) $(2.5 \mathrm{~mm})$ and $\mathrm{d}_{2}$ is external tube diameter $(8.0 \mathrm{~mm})$.

Equation 2 yielded the following values: $\Delta=1.63$; $\mathrm{C} / \mathrm{C}_{0}=9.22 \times 10^{-17} ; \mathrm{EC}=1-\mathrm{C} / \mathrm{C}_{0} ; \mathrm{EC} \approx 1(100 \%)$. In this type of sampling, the collection efficiency is usually assumed to be close to $100 \%$. The type of analyzer has a typically cylindrical design, which favors high values of efficiency. ${ }^{37}$

\section{Figures of merit}

The precision of the analyzer was examined using six different aliquots sampled from a FEP bag $(250 \mathrm{~L})$ containing $5 \mu \mathrm{g} \mathrm{L}^{-1}$ of formaldehyde. The system performed well, showing an average formaldehyde concentration of $5.57 \mu \mathrm{g} \mathrm{L}^{-1}$ and a relative standard deviation of $0.48 \%$.

The proposed procedure presented good precision with a relative standard deviation of less than $8.6 \%$ for all determinations. The formaldehyde detection limit was $0.55 \mathrm{ng} \mathrm{mL}^{-1}$ and was calculated as three times the standard deviation of the blank signal divided by the slope of the analytical curve. The linear range for formaldehyde determination was up to 0.87 at $9.84 \mathrm{ng} \mathrm{mL}^{-1}(\mathrm{y}=0.5555 \mathrm{x}+$ $1.5225 \mathrm{R}=0.9993$ ).

\section{Determination of atmospheric formaldehyde}

The FORMAL-FLU system was validated by comparison with a well-known HPLC method in which formaldehyde is collected in SEP PAK C18 cartridges coated with 2,4-dinitrophenylhydrazine (Table 2). The results obtained with the flow system, $0.74-1.94 \mathrm{ng} \mathrm{mL}^{-1}$ (average $=$ $1.32 \pm 0.51$ ), were compared with the 2,4-DNPHi reference procedure, $1.07-2.2 \mathrm{ng} \mathrm{mL}^{-1}$ (average $=1.59 \pm 0.61$ ), and no significant differences were found by a paired $t$-test with a 95\% level of confidence. This comparison revealed highly compatible results, confirming the applicability of the proposed method.

Table 2. A comparison study between the FORMAL-FLU system and HPLC method in the formaldehyde determination

\begin{tabular}{lcc}
\hline Method & FORMAL-FLU & HPLC \\
\hline Average & $1.32 \mathrm{ng} \mathrm{mL}^{-1}$ & $1.59 \mathrm{ng} \mathrm{mL}^{-1}$ \\
Standard Deviation & 0.51 & 0.61 \\
Limit of Detection & $0.55 \mathrm{ng} \mathrm{mL}^{-1}$ & $0.06 \mathrm{ng} \mathrm{mL}^{-1}$ \\
Limit of Quantification & $1.18 \mathrm{ng} \mathrm{mL}^{-1}$ & $0.17 \mathrm{ng} \mathrm{mL}^{-1}$ \\
$\mathrm{R}$ & 0.9993 & 0.9992 \\
\hline
\end{tabular}

Table 2 indicates that the HPLC method is more sensitive. However, the proposed system offers the following advantages: $(i)$ it does not require removal of particulates from the air; (ii) sampling and determination are integrated in a single device; (iii) it allows for in situ measurements; (iv) formaldehyde levels are measured in shorter time intervals; $(v)$ it is easily automated using computer controlled solenoid valves and data acquisition.

\section{Conclusions}

The low cost FORMAL-FLU system for determining formaldehyde in the vapor phase was developed for use with Fluoral-P, producing a fluorescent derivative 3,5-diacetyl1,4-dihydrolutidine (DDL). Heating the reaction coil increased the speed of the reaction, thereby enhancing 
the sensitivity of the method. The total formaldehyde determination time was reduced to $32 \mathrm{~min}$, and the system's collection efficiency was approximately $100 \%$, with a residence time of air of only $0.23 \mathrm{~s}$ inside the analyzer, confirming the good performance of the newly developed system.

The FORMAL-FLU analyzer has been used successfully in the determination of gas phase formaldehyde in both indoor and outdoor sites. The main advantages of the proposed system are its selectivity for formaldehyde, without relevant interference from bisulfite and other aldehydes, especially acetaldehyde, its low blank level, which provides low detection limits, and above all, the fact that it involves a single device for sampling and measuring, allowing for in situ measurements.

\section{Acknowledgments}

This work was supported by CNPq (National Research Council of Brazil), RECOMBIO, CTPETRO, CTENERG, FAPESB (Fundação de Apoio à Pesquisa do Estado da Bahia), CAPES (Coordenação de Aperfeiçoamento de Pessoal de Nível Superior), and FINEP (Financiadora de Estudos e Projetos). We are indebted to Prof. Dr. Wilson A. Lopes for his assistance with the figures.

\section{References}

1. IPCS, Formaldehyde; World Health Organization, International Program on Chemical Safety (Concise International Chemical Assessment Document No. 40): Geneva, 2002, p. 75.

2. Tanner, R. L.; Miguel, A. H.; de Andrade, J. B.; Gaffney, J. S.; Streit, G. E.; Environ. Sci. Technol. 1988, 22, 1026.

3. de Andrade, J. B.; Pinheiro, H. L. C.; Andrade, M. V.; J. Braz. Chem. Soc.1995, 6, 287.

4. Odabasi, M.; Seyfioglu, R.; Atmos. Environ. 2005, 39, 5149.

5. Tanner, R.L., Meng, Z.; Environ. Sci. Technol. 1984, 18, 723.

6. Goldschmidt, B. M.; J. Environ. Sci. Health 1984, 2, 231.

7. Andrade, M. V. A. S.; Pinheiro, H. L. C.; Pereira, P. A. P.; de Andrade, J. B.; Quim. Nova 2002, 25, 1117.

8. Pinheiro, H. L. C.; Andrade, M. V.; Pereira, P. A. P.; de Andrade, J. B.; Microchem. J. 2004, 78, 15.

9. Grosjean, D.; Environ. Sci. Technol. 1982, 16, 254.

10. de Andrade, J. B.; Miguel, A. H.; Int. J. Environ. Anal. Chem. 1985, 21, 229.

11. Salas, L. J.; Singh, L. J.; Atmos. Environ. 1986, 20, 1301.

12. Carlier, P.; Hannachi , H.; Mouvier, G.; Atmos. Environ. 1986, $20,2079$.

13. Miguel, A. H.; de Andrade, J. B.; J. Braz. Chem. Soc. 1990, 1, 124.
14. de Andrade, J. B. ; Tanner, R. L.; Atmos. Environ. 1992, 26A, 819.

15. de Andrade, J. B.; Andrade, M. V.; Pinheiro, H. L. C.; J. Braz. Chem. Soc. 1998, 9, 219.

16. Corrêa, S. M.; Martins, E. M.; Arbilla, G.; Atmos. Environ. 2003, 37, 23.

17. Corrêa, S. M.; Arbilla, G.; Atmos. Environ. 2005, 39, 4513.

18. Dong, S.; Dasgupta, P. K.; Environ. Sci. Technol. 1987, 21 , 581.

19. Dasgupta, P. K.; DeCesare, K.; Ullrey, J. C.; Anal. Chem. 1980, 52, 1912.

20. Miksch, R. R.; Anthon, D. W.; Fanning, L. Z.; Hollowell, C. D.; Glanville, J.; Anal. Chem. 1981, 53, 2118.

21. Walters, R. B.; Am. Ind. Hyg. Assoc. J. 1983, 44, 659.

22. Matthews, T. G.; Am. Ind. Hyg. Assoc. J. 1982, 43, 547.

23. Sawicki, E.; Hauser, T. R.; McPherson, S.; Anal. Chem. 1962, $34,1460$.

24. Sawicki, E.; Carnes, R. A.; Mikrochim. Acta 1968, 148.

25. Tsuchiya, H.; Ohtani, S.; Yamada, K.; Akagiri, M.; Takagi, N.; Sato, M.; Analyst 1994, 119, 1413.

26. Belman, S.; Anal. Chim. Acta 1963, 29, 120.

27. Compton, B. J.; Purdy, W. C.; Anal. Chim. Acta 1980, 119, 349.

28. de Andrade, J. B.; Bispo, M. S.; Rebouças, M. V.; Carvalho, M. L. S. M.; Pinheiro, H. L. C.; Am. Lab. 1996, 28, 56.

29. Oliveira, F. S.; Sousa, E. T.; de Andrade, J. B.; Talanta 2007, 73,561 .

30. de Andrade, J. B.; Pinheiro, H. L. C.; Andrade, M. V.; Int. J. Environ. Anal. Chem. 1993, 52, 49.

31. de Andrade, J. B.; Reis, J. O. N.; Rebouças, M. V.; Pinheiro, H. L. C.; Andrade, M. V.; Quim. Anal. 1996, 15, 144.

32. Grosjean, E. ; de Andrade, J. B. ; Grosjean, D.; Environ. Sci. Technol. 1996, 30, 975.

33. Pereira, P. A. P.; Santos, E. T. S.; Ferreira, T. F.; de Andrade, J. B.; Talanta 1999, 49, 245.

34. Nash, T.; Biochemistry 1953, 55, 461.

35. Esbensen, K. H.; Multivariate Data Analysis in Practice: An Introduction to Multivariate Data Analysis and Experimental Design, $5^{\text {th }}$ ed., New Jersey, 2002.

36. Ferreira, S. L. C.; Bruns, R. E.; da Silva, E. G. P.; dos Santos, W. N. L.; Quintella, C. M.; David, J. M.; de Andrade, J. B.; Breitkreitz, M. C.; I. Jardim, C. S. F.; Neto, B. B.; J. Chromatogr. A 2007, 1158, 2.

37. Williams, E. L.; Grosjean, D.; Environ. Sci. Technol. 1990, 24 , 811

Received: June 27, 2008

Web Release Date: December 12, 2008

FAPESP helped in meeting the publication costs of this article. 